\title{
The Cultural Logic of Martin Boyd's Anti-Puritan Novels
}

\section{Pat Dobrez, ANU, Canberra}

\begin{abstract}
My inner division ... is the age-old one of the European between the Mediterranean and the north, the Classic and Gothic worlds.

Martin Boyd, Day of My Delight.
\end{abstract}

Reflecting on his life and writing, a twentieth-century Australian novelist - who, translated into Czech, Danish, Norwegian, Swedish and Italian, has enjoyed as large a readership in Europe as in the country of his birth - confessed to being "all for sweetness and light" (Boyd 1965b:147). In this way he aligned himself with the "Hellenic" term of the Hebraic/Hellenic opposition Matthew Arnold wished resolved in happy balance. Boyd's self-characterization underlines what is abundantly apparent from the novels themselves, namely their author's dependence on a European debate of the previous century. From the post-WWI years to the 1960s Martin Boyd [1893-1972] spun narratives out of journeys between the poles of north and south. The geographical settings of these journeys are often European, until he finds his métier writing fictionalized autobiography and family history, and turns his attention to what he calls the "geographical schizophrenia" of colonials forever on the move between hemispheres (1965a:95). A member of the Australian à Beckett-Boyd family of artists, renowned from the early days of the Victorian colony after William à Beckett (brother of London Punch's Gilbert à Beckett) travelled to Australia to become Victoria's first Chief Justice, Martin Boyd took up the example of his great-grandfather William's social criticism to practise an art of fiction Arnoldian in temper. His novels and his venture in the 'Italian journey' genre range over cultural ground made familiar to generations of schoolboys in England and Australia through Culture and Anarchy. Typically Boyd's novels provide a testing ground for Arnold's central hypothesis: "Hebraism and Hellenism, - between these two points of influence moves our world" (Arnold 1956:90).

Unlike his forebear who was never at home in Melbourne, Martin Boyd, 'native born' and growing up in an idyllic environment with artist parents who were connected through the Victorian Artists' Society to the so-called 'Heidelberg School' (named after artists' camps at Heidelberg on the outskirts of Melbourne), remembered his childhood as having taken place during a Golden Age when "Melba sang in her native land" and "Tom Roberts, Conder, Streeton and the other great Australian painters" created an exciting scene (1964:8). Later, when he turned to the writing of fiction, Boyd strove for a literary equivalent of the painting of the Australian 1890s, having witnessed first-hand Victorian Artists' Society 
adaptations of impressionist techniques for the purposes of capturing local effects of colour and light. In the early novels his efforts are merely descriptive. It was only when he began to think about the nature of perception in a way reminiscent of Walter Pater that he developed a unique method of approaching his fictional subjects, one which allowed him to capture the fugitive in experience.

Martin and his painter brother Penleigh accompanied their parents on painting excursions, making of their lives an informal picnic. If Arthur Streeton and Tom Roberts in the late 1880s could celebrate a hedonistic way of life in paintings with titles like "Boys Bathing, Heidelberg" and "The Sunny South", Martin could write lyrically of the pleasures he experienced during his boyhood at the turn of the century. The Boyd children owned ponies, had the advantage of river frontage for swimming, and could hunt, fish and pluck fresh fruit from orchard trees. Day of My Delight recalls these halcyon days when "leisure and freedom were unrestricted" and it seemed as if they were living in "a place of perpetual sunlight" (Boyd 1965b:24-25). Given this early experience it is not surprising that the novelist's perennial focus is an enquiry into the manifestations of culture in hot climates.

Martin Boyd looked for ways in which the new country might overcome its inheritance from the culture of a colder climate to make the most of possibilities for an experience rich in sensuous pleasure. In The Cardboard Crown his narrator Guy Langton comments that the Australian landscape is sun-drenched and in it "one would not be surprised to see a frieze of naked Spartans" (1971a:23). In The Montforts, Raoul Montfort Blair is Boyd's mouthpiece arguing for a similarity between the European south and Australia:

In Australia Raoul had associated all true civilization with the cool green countries of the north, where only hitherto he had found it. A hot climate had for him inevitably meant newness and crudity. Yet here in a climate not unlike that of districts around Melbourne, had flowered an art and culture, the greatest since that of Greece in the fifth century B. C. This similarity of climate seemed to give Australia a greater value in his eyes, finer potentialities (1975:240).

Boyd's making the classical south his touchstone would appear blinkered to a later generation, and one capable of questioning colonial assumptions. Sidney Nolan, from the 1940s a friend of Martin's painter nephew Arthur Boyd and later married to Arthur's sister Mary, observed that, when it comes to living in Australia, everything is to be learned from Aboriginal people. Visiting the outback in 1950 he wrote: 
They give you the key to the whole situation. ... They show us that the country is a gentle dreaming one, the barrenness \& harshness is all in our European eyes and demands. In fact one feels a barbarian at the gates (cit. in Smith:12).

A man of his times, Boyd was incapable of standing outside the Western cultural tradition to ask questions about indigenous interpretations of the land. Because he was always constructing identity within a borrowed framework, he remained ignorant of existing mythological stories. Indeed he needed to send his character Raoul back to the European south, to Italy, in order that the latter might learn necessary lessons about the "finer potentialities" of Melbourne. In acknowledging this blind spot it is interesting to note that the mature Boyd is less optimistic about the future of Australia than the young writer fired by Victorian enthusiasms. For all his reminiscing about an Australia experiencing first flush nationalism, Boyd lived most of his life as an expatriate, spending his last fifteen years in Rome, where, as a non-Italian national, he is buried near Keats and Shelley in the Cimitero acattolico.

As he developed his art of fiction from frivolous beginnings, Boyd began to reveal affinities with writers in the English tradition whose admiration for the Greeks matched that of Winckelmann and Goethe, to the extent that it is accurate to describe him as Walter Pater's Australian disciple. Towards the end of the first edition of The Montforts he has Raoul write absurdly romanticizing verses (deleted from the revised edition of 1963) about the European south in which the voice of Victorian Hellenists can be heard: "Ah, by the sapphire of Hellenic seas/Stand naked in the sun..." (1928:315). The deletion of Raoul's poems has more to do with Boyd's later embarrassment about their tone than the drift of the novel. In both editions of The Montforts making the most of life in a hot climate is seen in terms of a pursuit of classical values understood in the Victorian sense. This is Boyd's pre-eminent focus throughout his writing life right up to his last-published novel, a light-hearted affair which reworks the dream of the south as comedy. Here it is said of the central character that "like Winckelmann, she was forty and she longed for the south" (1969:17). The joke doubtless has its origin in Pater's comment in his Winckelmann essay: "But his hair is turning gray, and he has not reached the south" (101).

The two pilgrims undertaking their Italian journey in Much Else in Italy comment on their experiences in terms of opposed classical and mediaeval ideals. This evaluative scheme - which in Arnold and Pater owed much to a study of German Hellenism from Winckelmann to Heine - is encountered in many guises as the English nineteenth century, still dreaming of a Hellas conjured by Byron, moves to 
its hedonistic conclusion. The polemic swings to extremes in Swinburne's pagan enthusiasms and Pater's assertion of the superiority of the Greek imagination, fluctuates in the writings of William Morris, and reaches its exhibitionist apotheosis in Oscar Wilde's enfant terrible parading of the fashionable pursuit of "Hellenism" (read hedonism) in the story of "Dorian" Gray. In The Nature of Gothic John Ruskin - indebted perhaps to Black's English translation of A. W. Schlegel - gives the terms of the English debate its geographical dimension:

The charts of the world which have been drawn up by modern science have thrown into a narrow space the expression of vast amounts of knowledge, but I have never yet seen one pictorial enough to enable the spectator to imagine the kind of contrast in physical character which exists between Northern and Southern countries (185-86).

The scene is set for a Martin Boyd to make his own investigation of the effects of geography and climate on culture and to approach the binary of Hebraic/Hellenic within the expanded framework of a north-south opposition reinterpreted from the perspective of the antipodes.

Boyd made the most of contrasts between England and Australia for the purpose of elaborating his hellenizing, that is to say anti-puritan, stance. Beauty and pleasure are to be celebrated in the face of philistine - to use the word Arnold borrowed from Heine (1964:100) - antagonism. There is a privileging of the European south in the construction of plots which repeat the pattern of a novelist like E. M. Forster setting scenes of liberated sensuality in Italy. In one of Boyd's 1930s apprentice novels set in England, Scandal of Spring, a young man of English and Italian parentage has mismatched eyes: one blue and one brown. For a large part of the story his brown eye is bandaged, but at a cathartic moment complete vision is restored in an event intended to symbolize the resurgence of his Mediterranean soul: "he had returned to the beginning of the world, to a clear golden age" (1934:201). A preoccupation with the south as catalyst in the process of his characters' liberation continues in Boyd's narratives concerning AngloAustralian families moving between hemispheres. In the long run these people are southernized, and whenever they return 'home', are soon lured away from their English estates in search of warmer climes. Boyd is at is best when he is writing about what concerns him most, namely the colonial predicament. The north-south binary is presented in almost algebraic form in the plots and character types of lesser novels (as illustrated by Scandal of Spring), while in the mature fiction it is vibrantly represented not only in contrasts of European and Australian landscapes, painterly in conception and rendering, but in a more complex and evocative treatment of character and event. 
A narrative pattern informed by an Australian version of Henry James' notion of the 'complex fate' of Europeanized Americans is established early in The Montforts. Inevitably Boyd's colonials puzzle over their schizophrenic lives. They are periodically drawn back to Europe, to-ing and fro-ing until Raoul Montfort Blair emerges as the type of a new breed who, having experienced the call of the antipodean south, expresses views akin to Boyd's own when the novelist conflates aesthetics and ethics in an article for Southerly: "Italians say of a thing that is morally bad, that it is ugly" (1968:89). It was a Renaissance maxim that an Englishman Italianate is the devil incarnate; Boyd is nothing if not an Australian Italianate. Like their 1928 predecessor, The Picnic (a thirties novel), Lucinda Brayford (Boyd's World War II pacifist novel) and the Langton tetralogy (which appeared in the decade 1952-1962), all follow the fortunes of families living in a world divided between northern and southern hemispheres. The attraction of the Victorian discourse as a means of interpreting this state of affairs is irresistible. In any case Boyd draws on it in novels set in England, but when Australian-European comparisons come into play, Arnoldian and Paterian ideas about restraint and freedom to pursue beauty and pleasure acquire fresh resonance as they are exported to the antipodes. The 'south' in the European north/south binary is enlarged to include Australia, in particular Melbourne and environs. The north, however, remains the term opposed to both the European (classical) south and Australia.

In the Anglo-Australian novels we encounter a binary within a term of a binary: there is a south which provides the setting for a pleasurable existence, and there is a south which represents fatal passions. I shall attempt to outline the operation of the binary and its ambivalent southerly term in the Langton novels, accepted as Boyd's most accomplished work, and shall do so with reference to Much Else in Italy, an account of a journey in which three pieces of sculpture mark stages of enlightenment, beginning with an engagement with the Hellenic and ending with a return to the Hebraic which does not, however, extinguish the Hellenic fire. In this anachronistic book the influence of Pater - asserting that "the Greek ideal expressed itself pre-eminently in sculpture" (113) - is obvious. Boyd's emphases are precisely those identified by Richard Jenkyns as Pater's: "Pater quietly conflates two different themes, the Greeks' cult of handsome young men and the idea that in Greece mankind experienced its youth and childhood" (150). Both these ideas feed into Boyd's myth of an innocent and also youthful Australia.

In the Langton books Boyd allows himself an extended narrative of parallel lives for the purpose of unfolding the fortunes of a family reluctant to cut their ties with their English estate. The name Langton is borrowed from the first known burial in the Cimitero acattolico - that of a 1738 Oxford student - thus strengthening the 
idea of the lure of Rome for provincials. The narrator is Guy Langton, an Australian-born aesthete who assembles his material as a set of impressions, placing "dots of contradictory colour next to each other" - as he informs the reader in A Difficult Young Man (1965a:26). Attracted by both the north and the south, Guy articulates an antipodean version of the "inner division" Boyd speaks of in his autobiography (1965b:239):

Waterpark was the magnet which drew my family back ... just as they might have been thrusting their roots fruitfully into Australian soil ... the family [were] ... whisked backwards and forwards-to Westhill when they felt the cold, to Waterpark when they felt the heat ...

The contrast between their English and Australian homes is extreme, and at the outset of the story we have no sense of the family having "arrived" in the sense in which Raoul has become adapted to life in Australia by the end of The Montforts. Guy, who in a later novel will reveal the intensity of his youthful attraction to the north, articulates (in The Cardboard Crown, 1971) that he was "probably happier" at Waterpark

than at Westhill, where I felt the countryside to be large and frightening with so much dead timber, with snakes and scorpions, with magpies which snapped their beaks like a pistol shot ... Sometimes in the summer to go out of doors was like entering a vast scorching oven ... (1971a:43-44).

The spectacle of opposed hemispheres begins to structure the narrative as a simple fact of geography but, in the course of the Langton books, the binary Boyd encountered in his nineteenth-century English sources will be shaped to the Australian situation and used for new, particular, and idiosyncratic ends.

In the first instance Boyd sets out to characterize what is peculiar to the Australian scene. The Montforts, newly-arrived in the colony, are dazzled by "blood-red" sunsets, confront huge ants and suffer snake bite (1975:23,41). A crinolined young woman floating through saplings to meet her lover is attacked by a magpie in an episode which might well have provided Arthur Boyd with a template for his painting of Adam and Eve's expulsion, except that at this stage the landscape in the novel is untouched by story, either biblical or classical. In other words, it is untouched by "civilization". At first glance the Australian scene as depicted in The Cardboard Crown also suggests malice in its rawness and unpredictability. Such a value-laden reading of the south, which draws its rhetorical power from the naturenurture distinction, exists as an othering stereotype in European literature in, for example, Madame de Staël's Corinne, or Italy, where Italians are described as 
exhibiting "in turn, unexpected marks of generosity and friendship or dark fearsome proofs of hatred and vengeance" (102); or in E. M. Forster's A Room with a View, where Italy is both a site of violence and liberation. To employ LéviStrauss' anthropological binary out of context, there is a discourse of a "raw" south and a "cooked" south, just as concepts of a "rude and wild" north and aspiring noble north inform Ruskin's descriptions of landscape and Gothic architecture (185-88).

Something different is at work in The Cardboard Crown, where the novelist is eager to avoid suggestions of an ethico-cultural either/or. If we attend closely to the Paterian impressionism of Guy's narrative we see how unlike The Montforts the later novel is. What we encounter is a contemplative antinomianism communicated to the reader via juxtaposed figures, scenes and stories which, whatever their diverse sources, are received by a sensibility (Guy's) open to a rich and varied experience.

It is the advantage of first-person narration in the Langton books that the south can be presented to the reader pre-interpreted by a member of the 1890 s generation. The vision of a new Hellas does not await the coming of a Raoul, for a hellenizer is heard from the outset in the voice of the story-teller. As Guy elaborates comparisons with ancient Greece, a figure emerges from the landscape in this "most ancient of all lands, where the skeletons of trees extend their bleached arms in the sun, and giant lizards cling to their trunks": "in this scene the first human being I visualize is not a Spartan boy, but the small black figure of cousin Hetty". An arresting figure, a "tigress" with fierce "Savanarola eyes", Hetty sets out to seduce Austin, the husband of gentle, restrained Alice (1971a:22, 23, 37, 27), but in so doing she sets Alice on a path of self-discovery in which her senses are awakened and her relationship with Austin is renewed. A myth-maker from the moment he begins to narrate, Guy structures his story in terms of an ascent in which his characters are initiated into the mysteries of love. There is an optimistic sense that, despite misgivings about the character of the land, we are moving in a benign universe. As Byron put it in Don Juan, Canto 1, stanza 63: "What men call gallantry, and gods adultery,/ is much more common where the climate's sultry". With ethical considerations thus disposed of, the crudely-split, value-bearing binary of a south that is either "raw" or "cooked" collapses.

As the narrative progresses it is clear that Guy is focused on images of pleasure. In the familiar pattern of the Boyd novel, Alice finds herself in Italy where a temperate climate, Virgilian villas and Renaissance art open out new prospects. Under the tutelage of a modern Italianate Englishman, she surrenders to the influence of her surroundings: 
... I had no conception of what beautiful places there were in the world until I came to Italy ... There is very striking scenery in Australia, and the view even from Westhill is magnificent, but it has not the same connexion with humanity (1971a:91).

Acknowledging what she has learned from the classical south, Alice names the child born out of her reunion with Austin 'Diana'.

The narrative of hellenization continues in Outbreak of Love where Diana, married, like Alice, to an unfaithful husband, becomes the vehicle for a new appreciation of the Australian landscape. Through his love-making, the husband Wolfie von Flugel (sic) interprets memories of his birthplace in classical terms, unveiling

the splendid mysteries which to him were the vineyards of the Rhine and the apple orchards of Bavaria. They awoke in him intimations of a greater antique glory, the breasts of Ceres and the tumbling grapes in a Sicilian winepress ... (1971b:21).

Wolfie may owe not a little to Pater's Imaginary Portraits sketch of a provincial aesthete who desires an 'Apolline' awakening in Germany, with the difference that it is Melbourne and not the southern German towns - where "the overflow of Italian genius was traceable" (124) - which provides the setting for an awaited 'Aufklärung' (152). Possessed by amoral desire, Wolfie is affectionately addressed as "dingo" by his unsubtle mistress. In the main, the adulterous affair is treated as comedy by Guy intent on evoking the pleasures of la belle époque. Wolfie's behaviour gives Diana the freedom to pursue a friendship with still another Italianate aesthete, an Australian who has been mentored by her mother. Her guide in matters cultural turns obsessively to Italy as pivotal point in the HebraicHellenic balancing act:

... in Italy you find all the things that have made us what we are - classicism the basis and Catholicism fused into one and the effect is tremendous. We find our place in history. That is why we can only live elsewhere, when we regard ourselves as a province of Rome. (1971b:102)

England is well off the radar: "a far outpost where the inhabitants of that damp northern island had tried to echo the religion and splendours of their true home, which for every civilized man is the Mediterranean" (1971b:102). 
It is a work of fiction with faint Goethean and Paterian echoes (in preparation as Outbreak of Love went to press) which supplies the interpretative framework for understanding all the Langton books as an extension of the Hebraic-Hellenic debate. To the very end Boyd attempted to clarify his position in respect to the question Matthew Arnold had posed for him. Speaking of Heine's "religion of pleasure" a worried Arnold had asked: "Can a man live by it?" (1964:131). Boyd was less cautious. In a symbolic equivalent of those outbreaks of unbridled passion in the affairs of Hetty and Wolfie, the cultural pilgrims of Much Else in Italy receive their first epiphany at the Etruscan Museum in Rome when they are charmed by a sculpture announcing "the spiritual condition in which, in our times of health, we are satisified to be". If they have qualms about the Veii Apollo representing "too savage" a god for unconditional veneration, they receive it as a Blakean celebration of energy as "eternal delight" prompting them to continue their search for a "beauty long desired". A second Apollo has bearings on Boyd's portraits of Alice and Diana. With their discovery of the 'Apollo of Tevere', a Roman copy of a Greek original exhibited at the site of the Diocletian Baths, the travellers intuit a state in which "the body is in harmony with the serene mind" $(1958: 35,18,127,43)$.

The Hebraic-Hellenic dialectic reaches a new phase in the second and fourth narratives in the Langton sequence - novels concerning the life and personality of Guy's brother, Dominic. It is significant that Guy's memories of Dominic in $A$ Difficult Young Man are filtered through the "prolonged mediaeval dream" (1965a:116) of the narrator's youth. Dominic himself - seen by Guy as a Tennysonian knight with the southern passions of a Spanish ancestor - elopes with his cousin (appropriately named 'Helena') in a dramatic resurgence of latent sympathies. For the length of Guy's narrative Dominic is engaged in spiritual warfare with antipodean puritans and barbarians who cross his path, thus evoking for us once again the central Arnoldian theme. In this book, and in When Blackbirds Sing (which continues the story of Dominic against the backdrop of the 1914-18 war), Boyd overwrites his elaborations of northern values with meditations on Gothic art and mediaeval religion, engaging Arnold himself (1964:128-29), as he does in the Italian travelogue (1958:144-48), on the subject of Saint Francis as a type of human perfection (1971c:70). In the youthful Guy's mediaevalism and his search for the "Memlinc ... in the cellar ... the beautiful portrait of the human face lost in the dissolution of our family and tradition" (1965a:161) there is a concession to Arnold's point that when we consider human suffering we must acknowledge that the Middle Ages' "religion of sorrow has such a vast advantage over a religion of pleasure" (1964:132). 
For the soldier Dominic there is no resolution to the problem of divided allegiances as he switches loyalties from south to north, from his Australian wife to his English mistress Sylvia, suffering a mental torment whose only alleviation is found in the glimpse of wholeness afforded by visionary identification with a German boy he kills in hand-to-hand combat - in an episode which recalls Wilfred Owen's poem "Strange Meeting". The philistines and barbarians of this book are those responsible for the conduct of the war on both sides. Suggestions of a Christlike figure at the outset of The Cardboard Crown are never fulfilled in the Langton books, as a projected fifth novel never materialized. Guy's presentation of Dominic at the end of his life painting a crucifix -

the tortured body, the face hidden by hanging hair, the conspicuous genitals. It was something that could not properly be shown, except to Trappist monks on Good Friday (1971a:15)

- is contrary to the image of a redemptive beauty-for-others which constitutes the third epiphany of the Much Else in Italy pilgrims: the hellenized Christ of Michelangelo's Pietà - a sculpture which speaks of the religion of the early church insofar as it retains "something like the light that shone on the head of the Apollo of Tevere" (1958:57-58).

Boyd shared Arnold's critical habit and did not scruple to challenge the views of those from whom he had learned most. Considering this it seems appropriate to end by confronting the fact that he does not escape the kind of criticism which has been levelled at Arnold on account of his race theories. Although he was at pains to distance himself from eugenicists - this is seen in Raoul's rejection of his mentor Broom's desire to "breed out" the weak (1975:243) - there is enough going on in Boyd's family sagas to suggest a worrying double-talk. Ideas about improving the stock, like those articulated in The Montforts, circulated in Australia in the twenties and thirties, as Christina Stead's negative portraits of eugenics promoters testify. References to "race and ancestry" (1975:9) abound in Boyd and, if he manages to avoid the harshest of judgements, it is not difficult to conclude that he was indeed a cultural exclusivist for whom the Graeco-Christian story represented the entire historical horizon.

A hypothetical. What would he have thought, if like the protagonist of Morris's News From Nowhere - Boyd was an admirer of this utopian fin-de-siècle novel he could have travelled to the future, turning up at the National Museum in Canberra in the summer of 2008 to view an exhibition of artworks from Central Australia, desert paintings of the scale and brilliancy of the Papunya people's canvases mapping their homelands in an unfamiliar dot-point technique? Would 
he even recognize these works as Australian landscape paintings? Would he praise their reenactments of ancestral journeys as myths to live by? Would he recognize their 'dreamings' as potent mediations of a vibrant living culture? Would he see them as speaking of the "morning of the world" (1971a:56) in the same way as the cultivated landscape of settler Australia, which he so appreciated? Reading Boyd's novels, we may stumble on a character speculating about "cave-men" or "remote aboriginal heathen gods" (1928:308,153), but references are fleeting and their occurrence rare. Of course there is something which would astonish him still more, and threaten his entire cultural logic: climate change.

\section{Bibliography}

Arnold, Matthew, [1869] 1956. Culture and Anarchy, An Essay in Political and Social Criticism. London: John Murray.

Arnold, Matthew, [1865] 1964. Matthew Arnold's Essays in Criticism, First Series, ed. T. M. Hoctor. Chicago: University of Chicago Press.

Boyd, Martin [Martin Mills pseud.], 1928. The Montforts. London: Constable.

Boyd, Martin, 1934. Scandal of Spring. London: Dent.

Boyd, Martin, 1958. Much Else in Italy, A Subjective Travel Book. London: Macmillan.

Boyd, Martin, 1964. "Dubious Cartography". Meanjin, XXIII (1), 5-13.

Boyd, Martin, [1955] 1965a. A Difficult Young Man. Revised edition. Melbourne: Lansdowne.

Boyd, Martin, 1965b. Day of My Delight: An Anglo-Australian Memoir. Melbourne: Lansdowne.

Boyd, Martin, 1968. "Preoccupations and Intentions". Southerly,28 (2), 83-90.

Boyd, Martin, 1969. The Tea-Time of Love: The Clarification of Miss Stilby. London: Geoffrey Bles.

Boyd, Martin, [1952] 1971a. The Cardboard Crown. Revised edition. Melbourne: Lansdowne.

Boyd, Martin, [1957] 1971b. Outbreak of Love. Revised edition. Melbourne: Lansdowne.

Boyd, Martin, [1963] 1975. The Montforts. Revised edition. Melbourne: Lansdowne.

Boyd, Martin, [1962] 1971c. WhenBlackbirds Sing. Melbourne: Lansdowne.

Madame de Staël, [1807] 1998. Corinne, or Italy. Oxford: Oxford University Press.

Jenkyns, Richard, 1980. The Victorians and Ancient Greece. Oxford: Basil Blackwell. 
Pater, Walter, 1948. Walter Pater, Selected Works, ed. Richard Aldington. London: William Heinemann.

Ruskin, John, [1853] 1904. The Stones of Venice, Volume II. London: George Allen.

Smith, Geoffrey and Smith, Damian, 2003. Sidney Nolan: Desert and Drought. Melbourne: National Gallery of Victoria. 